\title{
Abundance and instantaneous transport of Petrolisthes armatus (Gibbes, 1850) planktonic larvae in the Catuama inlet, Northeast Brazil
}

\author{
MAURO DE MELO JÚNIOR ${ }^{1}$, RALF SCHWAMBORN ${ }^{2}$, \\ SIGRID NEUMANN-LEITÃ̃ ${ }^{3}$ and MARYSE N. PARANAGUÁ ${ }^{4}$ \\ ${ }^{1}$ Universidade Federal Rural de Pernambuco, Unidade Acadêmica de Serra Talhada, \\ Fazenda Saco, s/n, Caixa Postal 063, 56900-000 Serra Talhada, PE, Brasil \\ ${ }^{2}$ Universidade Federal de Pernambuco, Departamento de Zoologia, \\ Av. Professor Moraes Rego, 235, 50740-550 Recife, PE, Brasil \\ ${ }^{3}$ Universidade Federal de Pernambuco, Departamento de Oceanografia, \\ Av. da Arquitetura, s/n, 50670-901 Recife, PE, Brasil \\ ${ }^{4}$ Universidade Federal Rural de Pernambuco, Departamento de Biologia, \\ Av. Dom Manuel de Medeiros, s/n, 52171-900 Recife, PE, Brasil
}

Manuscript received on April 5, 2010; accepted for publication on June 8, 2010

\begin{abstract}
The influence of tidal and diel changes on the exchange of Petrolisthes armatus planktonic larvae was studied at the Catuama inlet, which represents an intermediate system of marine and estuarine environments in the Northeast Brazil. To characterize the larval abundance and vertical distribution, samplings were carried out in August 2001 at neap tide and 3 stations, with 3 hours interval over 24 hours. Samples were taken at three or two depths at each station, with a plankton pump coupled to a $300 \mu \mathrm{m}$ mesh size net. Petrolisthes armatus zoea I and II showed a mean of $26.3 \pm 83.6$ and $12 \pm 38.8$ ind $\mathrm{m}^{-3}$, respectively. During flood tides, the larvae were more concentrated in the midwater and surface, which avoided the transport to internal regions. In contrast, during ebb tides when the larvae were distributed in the three layers, the higher concentrations were found in the bottom, which avoided a major exportation. The diel dynamic of the larval fluxes was characterized by vertical migration behavior associated to the tidal regime, which suggested that the development of this decapod apparently occurs in the inner shelf (instead of the outer shelf) off this peculiar ecosystem.
\end{abstract}

Key words: Northeast Brazil, decapod larvae, Petrolisthes armatus, estuarine inlet, transport, zooplankton.

\section{INTRODUCTION}

Larvae of estuarine invertebrates continually face possible exports from the parent estuary (Cronin 1982), and the consequences of this flow are ecologically important. For instance, the export of decapod larvae from estuaries enhances geographic

Correspondence to: Mauro de Melo Júnior

E-mails: mmelojunior@gmail.com /

m_melojunior@yahoo.com.br dispersal and the avoidance of high predation pressure found in these ecosystems (Morgan 1990). However, the act of being transported to unfavorable habitats can result in severe problems for larvae of some species. Certain decapod crustaceans can even present behavioral or morphological adaptations in order to remain in or adjacent to the parental environment (Cronin 1982, Epifanio 1988, Morgan 1992, Morgan and Christy 1997, Fernandes et al. 
2002, Yannicelli et al. 2006). Despite the extensive literature on recruitment and dispersal of estuarine and coastal crabs, little is known about the patterns of larval abundance in tropical estuaries and coastal ecosystems (Dittel and Epifanio 1990), especially in Brazil (Schwamborn et al. 1999, NegreirosFransozo et al. 2002, Koettker and Freire 2006). Most of these studies focus on brachyuran crabs, while other taxa are poorly investigated.

The green porcelain crab, Petrolisthes armatus (Gibbes 1850) (Anomura: Porcellanidae), is a filter feeder found in tropical and subtropical regions of the Atlantic and eastern Pacific oceans (Haig 1960). In Brazil, this species occurs in the coastal line from Maranhão to Santa Catarina states, beyond the Fernando de Noronha Archipelago (Melo 1999). The adults of this crab can be found in high densities under rocks, mainly in estuarine and coastal ecosystems (Gore and Abele 1976, Coelho 2000). Furthermore, this crustacean is clearly the single dominant porcellanid species in northeast Brazilian estuaries (Coelho 2000, R. Schwamborn et al., unpublished data).

In studies performed in laboratory, Petrolisthes armatus hatches into a pre-zoeal stage that lasts approximately one hour, molts through two subsequent zoeal stages, and then develops to a megalopal stage (Gore 1970). In relation to its developmental period, this author observed that the first and second zoeal stages last about five and six days, respectively, at $28^{\circ} \mathrm{C}$, and the megalopal stage lasts a minimum of six days. Both zoeal stages are commonly found in estuarine and coastal waters (Dittel and Epifanio 1990, Schwamborn 1997, Magris and Loureiro-Fernandes 2005). The megalopal stage has been recorded as a commensal of the limpet Crucibulum (C.) spinosum (CamposGonzález and Macías-Chávez 1987) and is rarely found in the plankton.

Considering the biological aspects of porcellanid larvae found in Brazilian waters, only a few studies have focused on these developmental stages, and these investigations are predominately restricted to the distribution analysis at a family level (Schwamborn et al. 1999, Koettker and Freire 2006) possibly due to difficulties in the proper identification of the larval stages. Magris and Loureiro-Fernandes (2005) carried out a survey of porcellanid larvae in the Piraquê estuarine system, southeastern Brazil, and found high densities of P. armatus larvae, which represented the most abundant species in this area. In areas with high production of invertebrate larvae, the release and dispersal of $P$. armatus larvae constitutes the main pathway of energy transfer, from mangrove ecosystems to estuarine and marine pelagic food webs (Schwamborn et al. 2002).

The present study aims to evaluate the tidal and diel influences on the abundance and instantaneous transport of Petrolisthes armatus planktonic larvae in an intermediate system of marine and estuarine environments located in Northeastern Brazil. It was carried out by using a combination of high-resolution three-dimensional ADCP (Acoustic Doppler Current Profiler), current profiles and discrete plankton pumping techniques that operate vertically and horizontally.

\section{MATERIALS AND METHODS}

Plankton samples were taken at Catuama Inlet, which separates the northern margin of Itamaracá Island from the adjacent continent (Figure 1). The Itamaracá estuarine system is an important biological complex located approximately $50 \mathrm{~km}$ north of the city of Recife, northeastern Brazilian coast. For more details on this ecosystem, see Medeiros et al. (2001) and Melo Júnior et al. (2007).

The sampling program consisted of a full tidal cycle during neap tide (August 11-12, 2001) and was performed during the rainy season on a small vessel. The samples were collected with a pump at three fixed stations along one transect across the inlet. To assess the vertical distribution 


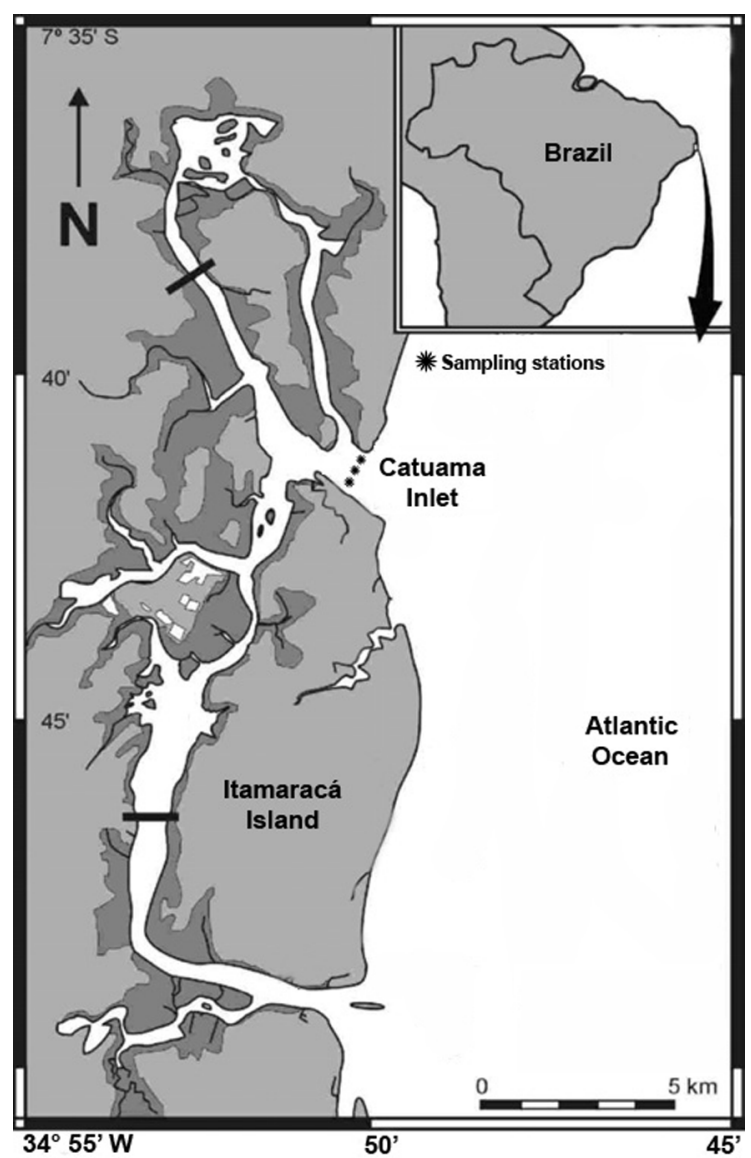

Figure 1. Itamaracá estuarine system (Pernambuco, Brazil) showing the Catuama Inlet and the sampling stations (indicated as marked).

and fluxes of the zooplankton, three depth levels were sampled $(50 \mathrm{~cm}$ below the surface, midwater, and $50 \mathrm{~cm}$ above the bottom) at the central station ( $\mathrm{Z}=\sim 15 \mathrm{~m}$ ), while samples were taken only at subsurface and above the bottom at both lateral stations $(\mathrm{Z}=\sim 10 \mathrm{~m})$. Water was pumped on board through a conical $300 \mu \mathrm{m}$ mesh plankton net for 3-5 min per sample, at approximately $100 \mathrm{~L}$ per min. At each station, samplings were conducted at $3 \mathrm{~h}$ intervals over a 24 hours period. All samples $(n=56)$ were immediately preserved in a $4 \%$ buffered formalin-seawater solution for later analysis.

Temperature and salinity were simultaneously measured with the zooplankton sampling using a CTD (Conductivity, Temperature and Depth profiler). Complete 3-D current profiles were obtained from one margin to the other with an ADCP probe mounted on a small vessel before each sampling series. In addition, current velocity and direction were continuously measured with the ADCP during plankton sampling at the three stations. At each sampling site, 10 random current velocity data were collected for depth and time. An average velocity for depth was obtained for each sampled station from these data.

Once in the laboratory, the Petrolisthes armatus larval abundance was estimated on the stereomicroscope by counting all organisms. Species identification and determination of the developmental stages followed several authors (e. g.: Haig 1960, Gore 1982). The larval abundance was calculated by the formula: $A=L^{*} V_{f}^{-1}$ (ind. $\mathrm{m}^{-3}$ ), where: $L=$ larvae number in the sample, and $V_{f}=$ total water volume filtered. To determine the whole instantaneous larval transport, we used the formula $T=A * C v$ (ind. $\mathrm{m}^{-2} \mathrm{~s}^{-1}$ ), where: $C v=$ current velocity $\left(\mathrm{m} \mathrm{s}^{-1}\right)$ for each moment of sampling. A Mann-Whitney U-test (Zar 1999) was used to determine significant differences in larvae density and transport between day and night, as well as at different sampling depths and tides (high, ebb, low, and flood). The relationship between instantaneous larval transport to temperature and salinity distribution were performed using the Spearman correlation analysis. All analyses were performed using the statistical program BioStat 5.0.

\section{RESULTS}

The average of the current velocity data was $0.26 \pm 0.14 \mathrm{~m} \mathrm{~s}^{-1}$, with vertical and horizontal heterogeneous current fields varying from 0.09 (flood) to $0.69 \mathrm{~m} \mathrm{~s}^{-1}$ (ebb). In general, higher values were observed in the surface layer during the ebb tide and in the bottom layer during the flood tide. The ADCP profiles indicated significantly higher values in the surface layers $(p<0.001)$, mainly during the ebb tides. The average temperature 


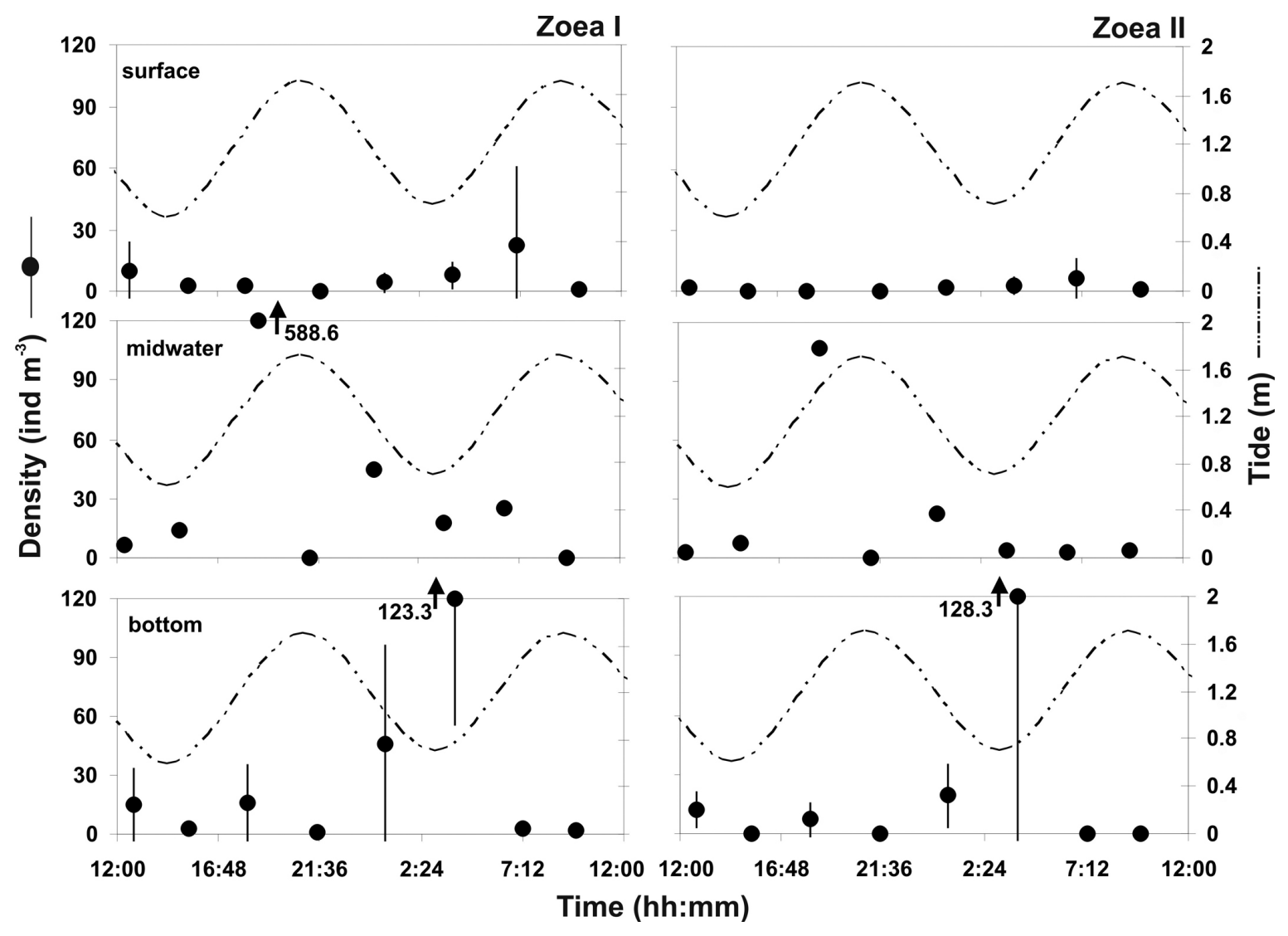

Figure 2. Density of Petrolisthes armatus larvae (ind. $\mathrm{m}^{-3}$ ) at Catuama Inlet (Northeastern Brazil) during a diel cycle (between August 11 and 12,2001). Standard deviations of the density are based on triplicate samples.

during the diurnal cycle was $25.8 \pm 0.3^{\circ} \mathrm{C}$, with a maximum of $26.5^{\circ} \mathrm{C}$ (surface layer, at $15: 30$ ) and a minimum of $25.3^{\circ} \mathrm{C}$ (bottom layer, at $15: 19$ ), which were both observed during the low tide. Salinity ranged from 28.3 (bottom layer, at 21:50, high tide) to 35 (surface layer, at 3:55, low tide) during the whole period, with a mean of $32.4 \pm 0.3$. Significant differences were found between the layers during ebb and low tides (bottom $>$ surface, both situations with $\mathrm{p}<0.001)$.

Peaks of Petrolisthes armatus zoeal density usually occurred around periods of flood tide, both diurnal and nocturnal (Figure 2). The mean density for zoea I was $26.3 \pm 83.6$ ind. $\mathrm{m}^{-3}$, with a maximum of 588.6 ind. $\mathrm{m}^{-3}$ at the midwater layer during the nocturnal flood tide. Higher values for this stage were observed in the bottom layer during the ebb and low tides $(\mathrm{p}<0.05)$. Zoea II showed an average density of $12 \pm 38.8$ ind. $\mathrm{m}^{-3}$ and a maximum at the bottom layer during the nocturnal low tide (128.3 \pm 123.4 ind. $\mathrm{m}^{-3}$ ), but the statistical analysis did not detect significant differences between mean values of variation, except during nocturnal ebb tide, when this stage showed higher values $(\mathrm{p}<0.05)$.

Zoea I of Petrolisthes armatus showed higher instantaneous transport rates during flood tides, with a maximum rate of 161.8 ind. $\mathrm{m}^{-2} \mathrm{~s}^{-1}$ (Figure 3) in the midwater layer during the crepuscular period. Higher values for this stage were observed in the bottom layer during the low tide $(\mathrm{p}<0.05)$. For zoea II, the major rate was also registered during the flood tide, in the midwater layer (28.5 ind. $\mathrm{m}^{-2} \mathrm{~s}^{-1}$ ). No statistical differences were detected for zoea II transport during the period. 


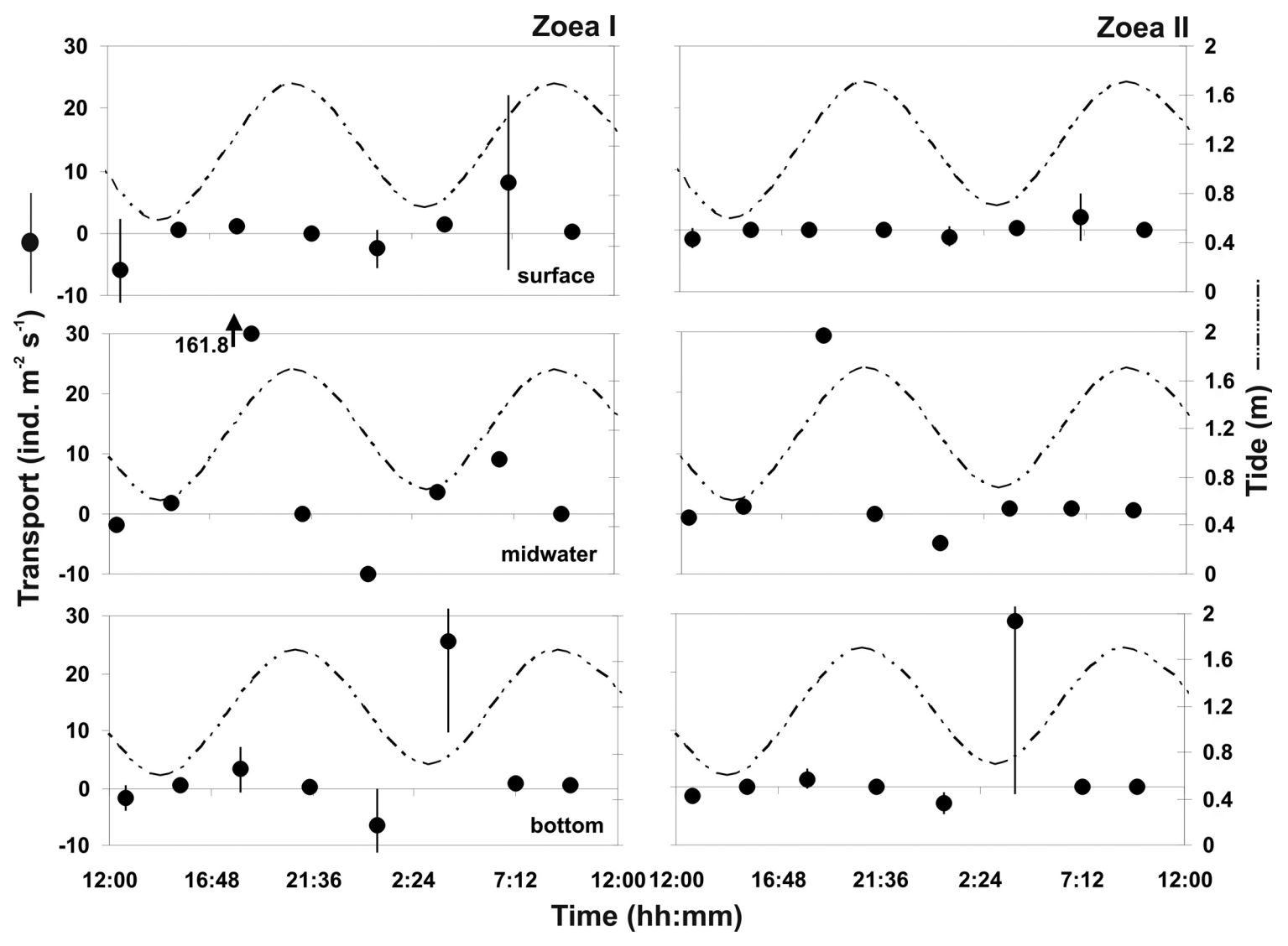

Figure 3. Transport of Petrolisthes armatus larvae (ind. $\mathrm{m}^{-2} \mathrm{~s}^{-1}$ ) at Catuama Inlet (Northeastern Brazil) during a diel cycle (between August 11 and 12, 2001). Standard deviations of the transport are based on triplicate samples. Positive values indicate larval import from the shelf area, and negative values indicate larval export from the Catuama inlet to the inner shelf area.

\section{DISCUSSION}

Vertical migration behavior of the Petrolisthes armatus zoea was associated with the tidal regime, which suggests that the development of this species probably occurs in the inner shelf off Catuama inlet. In general, high values of zoea were observed during low and ebb tides mainly in the bottom layers, which indicates the vertical migration of most of larvae to the lower layers during these situations. Even though this strategy is closer to Anger's scheme for larvae with retention mechanisms in the parental region (Anger 2001), we did not observe clear patterns maybe because of the limited sampling period. The larvae of $P$. armatus were distributed in the three layers during ebb tides, with higher concentrations in the bottom, which indicates that part of the population avoided the stronger surface currents and thus a higher exportation rate to less favorable areas. In contrast, the larvae were more concentrated in the midwater and surface during the flood tides, which avoided the transport to internal regions. However, the migration to surface layers occurred during the diurnal ebb tide, which could indicate some export to areas off Catuama inlet, as the inner shelf.

Schwamborn et al. (2002) showed the presence of the initial stages of Petrolisthes armatus in the coastal shelf adjacent to the northern sector of the state of Pernambuco, which suggests a likely export of zoea from the Itamaracá estuarine system and/or nearby coastal areas. The larvae found by these authors mainly in the inner shelf of this region (instead of the outer shelf), associated 
with the fact that this group has a considerable percentage (13 to $40 \%$ ) of mangrove carbon in its tissue (Schwamborn et al. 2002), indicate the idea that this species may preferentially develop in the near-shore coastal waters.

The occurrence of only zoea larvae in the plankton sampled from Catuama Inlet confirms partially the results presented by Campos-González and Macías-Chávez (1987) for the Mexican region of the Gulf of California. These authors showed that megalopae and juveniles of Petrolisthes armatus also form associations with other invertebrates, similarly to adults of Porcellanidae (Haig 1960, Hollebone and Hay 2008), thus narrowing the chance of these stages to occur in the plankton. Furthermore, Mascetti and Wehrtmann (1996) observed that megalopae of another porcellanid species (P. laevigatus) demonstrated a peculiar kind of behavior during laboratory studies, presenting thigmotaxis with floating objects and often forming small ball-like aggregations. When small broken shell pieces were present, such aggregations disappeared completely and megalopae spent most of the time hidden in the shell pieces, swimming sporadically (Mascetti and Wehrtmann 1996). However, megalopae and juveniles of Petrolisthes spp. have been recorded in plankton samples from other regions (Dittel and Epifanio 1990). Unlike the data presented herein, this previous study was conducted with horizontal trawling and using a plankton net as a collector device, which increased the chances of some floating substrates or even aggregates of more developed stages being captured during the sampling periods. Hence, other possible explanations for the absence of megalopae and juveniles of $P$. armatus in plankton samples from Catuama Inlet would be (i) the short period of study, which probably was not enough to detect advanced larval pulses, or (ii) the type of collecting device (suction pump) used in the present work, which is not effective in the capture of more developed stages in this species.
During the present research no clear larval export pattern from Catuama inlet was identified, which suggests at least that a part of the larvae is not exported in some situations. In this case, unlike the larval export that was evident in studies performed in estuarine systems by Dittel and Epifanio (1990) in Costa Rica, and by Magris and LoureiroFernandes (2005) in the Southeastern Brazil, why was a significant export pattern not found in Catuama inlet? This fact may be partially due to the physical conditions that create an intermediate system of marine and estuarine environments in this region (Medeiros et al. 2001). The high values of salinity corroborate that Catuama inlet is an intermediate system with predominantly marine conditions, rather than a bay-like area. Major larval exportations of this species most likely occur in the various estuaries that actually discharge into the Itamaracá estuarine system. Despite this, larval retention strategies in Porcellanidae have been indicated for a bay in the central region of Chile (Yannicelli et al. 2006), which also has the predominance of marine conditions.

The diel dynamic of the larval fluxes was characterized by vertical migration behavior associated to the tidal regime, which suggests that the development of this decapod apparently occurs in the inner shelf off this peculiar ecosystem. Considering the short developmental period ( $\sim 15$ days) of Petrolisthes armatus in the pelagic environment at temperatures above $25^{\circ} \mathrm{C}$ (Gore 1970), keeping most of the larvae in the inner shelf off Catuama inlet would be advantageous for the recruitment success in this area and, therefore, concords better with the high abundance of this species in these regions (Coelho 2000). However, we stimulate further studies to confirm this hypothesis since no clear patterns were found. Besides that, advanced larval stages of porcellanids seem to be more dependent to floating substrates, which provide protection against predation (Wehrtmann and Dittel 1990, Mascetti and Wehrtmann 1996, 
Schwamborn and Bonecker 1996). As the presence of this kind of substrate in oligotrophic regions becomes less likely as distance increases from the coastline, a larval export to the outer shelf off Catuama inlet could result in high losses of larvae and, consequently, affect the persistence of this population in this important ecosystem.

\section{ACKNOWLEDGMENTS}

We would like to thank the important suggestions and/or references from Ingo Wehrtmann (Universidad de Costa Rica), Michel E. Hendrickx (Universidad Nacional Autonoma de Mexico), and Gonzalo Hernandez (Universidad de Oriente). We are also grateful to the Conselho Nacional de Desenvolvimento Científico e Tecnológico (CNPq) for the financial support given for this study, and to the Coordenação de Aperfeiçoamento de Pessoal de Nível Superior (CAPES) for the Master scholarship (MMJr). Finally, we would like to thank the two anonymous referees for providing us with constructive comments and suggestions.

\section{RESUMO}

A influência dos ciclos de maré e fotoperíodo sobre o fluxo de larvas planctônicas de Petrolisthes armatus foi estudada na barra de Catuama, que representa um ambiente intermediário entre os sistemas marinho e estuarino no nordeste do Brasil. Para caracterizar a abundância e a distribuição vertical das larvas, foram feitas coletas em agosto de 2001, durante a maré de quadratura, em 3 estações fixas e com intervalos de 3 horas, ao longo de um ciclo de 24 horas. Em cada estação, amostras foram coletadas em três ou duas profundidades, com o auxílio de uma bomba de sucção acoplada a uma rede de plâncton com $300 \mu \mathrm{m}$ de abertura de malha. Os zoés I e II de Petrolisthes armatus apresentaram médias de $26,3 \pm 83,6$ e $12 \pm 38,8$ ind $\mathrm{m}^{-3}$, respectivamente. Durante as marés de enchente, as larvas estiveram mais concentradas nas camadas do meio e da superfície, evitando um transporte para regiões mais internas. Por outro lado, durante as marés de vazante, período em que as larvas estiveram distribuídas nas três camadas, as maiores concentrações foram encontradas no fundo, evitando uma maior exportação. A dinâmica do fluxo larval relacionada ao fotoperíodo foi caracterizada por migração vertical associada ao regime de marés, sugerindo que o desenvolvimento deste decápode aparentemente ocorre na plataforma interna adjacente (ao invés da plataforma mais externa) deste peculiar ecossistema.

Palavras-chave: Nordeste do Brasil, larva de decápode, Petrolisthes armatus, desembocadura de estuário, transporte, zooplâncton.

\section{REFERENCES}

ANGER K. 2001. The biology of decapod crustacean larvae. Crustaceana Issues 14: 1-419.

CAmpos-GonzÁlez E AND Macías-Chávez LJ. 1987. Fases posplanctonicas de Petrolisthes armatus (Gibbes) (Decapoda, Porcellanidae) comensales con la lapa Crucibulum (Crucibulum) spinosum (Sowerby) (Gastropoda, Caliptraeidae) en el Alto Golfo de California, Mexico. Rev Biol Trop 35: 241-244.

COElHo PA. 2000. Carcinofauna. In: BARROS HM, ESKINAZI-LEÇA E, MACEDO SJ AND LIMA L (Eds), Gerenciamento participativo de estuários e manguezais, Recife: Editora Universitária da UFPE, Recife, Brasil, p. 119-142.

CRONIN TW. 1982. Estuarine retention of larvae of the crab Rhithropanopeus harrisii. Estuar Coast Shelf Sci 15: 207-220.

DitTel AI AND EPIFANIO CE. 1990. Seasonal and tidal abundance of crab larvae in a tropical mangrove system, Gulf of Nicoya, Costa Rica. Mar Ecol-Prog Ser 65: 25-34.

EPIFANIO CE. 1988. Transport of crab larvae between estuaries and the continental shelf. Lect Notes Coast Estuar Stud 22: 291-305.

Fernandes LDA, Bonecker SLC AND VALENTIN JL. 2002. Dynamic of decapod crustacean larvae on the entrance of Guanabara bay. Braz Arch Biol Technol 45(4): 491-498.

GORE RH. 1970. Petrolisthes armatus: a redescription of larval development under laboratory conditions (Decapoda, Porcellanidae). Crustaceana 18: 75-89.

GORE RH. 1982. Porcellanid crabs from the coasts of Mexico and Central America (Crustacea: Decapoda: Anomura). Contrib Zool 363: 1-34. 
GORE RH AND ABELE LG. 1976. Shallow water porcelain crabs from the Pacific coast of Panama and adjacent Caribbean waters (Crustacea: Anomura: Porcellanidae). Contrib Zool 237: 1-30.

Haig J. 1960. The Porcellanidae (Crustacea, Anomura) of the eastern Pacific. Allan Hancock Pacific Expedition 24: $1-440$

Hollebone AL AND HAY ME. 2008. An invasive crab alters interaction webs in a marine community. Biol Invasions 10(3): 347-358.

KoetTKer AG AND FreIRE AS. 2006. The spatial-temporal variation of decapod larvae in the subtropical waters of the Arvoredo Archipelago, SC, Brazil. Iheringia, Ser Zool 10(1): 31-39.

MAgris RA AND LOUREIRO-FERnANDES L. 2005. Levantamento preliminar das larvas de Porcellanidae (Decapoda, Anomura) do sistema estuarino dos rios Piraquê-açú e Piraquê-mirim, Aracruz, Espírito Santo. Braz J Aquat Sci Technol 9(1): 49-54.

Mascetti P AND WehrtmanN IS. 1996. Aspects of the reproductive biology of Petrolisthes laevigatus (Guérin, 1835) (Decapoda, Anomura, Porcellanidae). Part III: effects of starvation and different types of diet on larval development under laboratory conditions. Arch of Fish Mar Res 43: 159-170.

Medeiros C, KJerfye B, AraúJo Filho M AND NeUMANNLEITÃO S. 2001. The Itamaracá Estuarine Ecosystem, Brazil. In: SEELINGER U AND KJERFVE B (Orgs), Ecological studies: coastal marine ecosystems of Latin America 144. New York: Springer-Verlag, New York, USA, p. 71-81.

Melo GAS. 1999. Manual de identificação dos Crustacea Decapoda do litoral brasileiro: Anomura, Thalassinidea, Palinuridea Astacidea. São Paulo: Plêiade/Fapesp, 551 p.

Melo Júnior M, Paranaguá MN, Schwamborn R, NEUMANN-LEITÃo S AND EKAU W. 2007. Fluxes of zooplankton biomass between a tidal estuary and the sea in Northeastern Brazil. Braz J Oceanogr 55(4): 239-249.

MORGAN SG. 1990. Impact of planktivorous fishes on dispersal, hatching, and morphology of estuarine crab larvae. Ecology 71: 1639-1652.
MorgAn SG. 1992. Predation by planktonic and benthic invertebrates on larvae of estuarine crabs. J Expl Mar Biol Ecol 163: 91-110.

Morgan SG AND CHRISTY JH. 1997. Adaptive significance of the timing of larval release by crabs. Am Nat 145: 89-101.

Negreiros-Fransozo ML, Fransozo A, GonZalezGORDILLO JI AND BERTINI G. 2002. First appraisal on releasing and reivasion of decapod larvae in a subtropical estuary from Brazil. Acta Limnol Bras 14(3): 87-94.

SCHWAMBORN R. 1997. Influence of mangroves on community structure and nutrition of macrozooplankton in Northeast Brazil. Bremen: ZMT 4: 77

SCHWAMBORN R AND BONECKER ACT. 1996. Seasonal changes in the transport and distribution of meroplankton into a Brazilian estuary with emphasis on the importance of floating mangrove leaves. Braz Arch Biol Technol 39: 451-462.

SCHWAMborn R, EkAU W, PINTO AS, Silva TA AND SAINTPAUL U. 1999. The contribution of estuarine decapod larvae to marine macrozooplankton communities in Northeast Brazil. Arch of Fish Mar Res 47: 167-182.

SChWAMBorn R, EKAU W, Voss W AND SAINT-PAUL U. 2002. How important are mangroves as a carbon source for decapod Crustacea larvae in a tropical estuary? Mar EcolProg Ser 229: 195-205.

WEHRTMANN IS AND DITTEL AI. 1990. Utilization of floating mangrove leaves as a transport mechanism of estuarine organisms, with emphasis on decapod crustacean. Mar Ecol-Prog Ser 60: 67-73.

Yannicelli B, Castro L, VAlle-LeVinson A, AtKinson L AND FigueroA D. 2006. Vertical distribution of decapod larvae in the entrance of an equatorward facing bay of central Chile: implications for transport. J Plankt Res 28: 19-37.

ZAR JH. 1999. Biostatistical analysis. New Jersey: PrenticeHall, New Jersey, USA, 663 p. 